\title{
The lichens of the Cladonia pyxidata-chlorophaea complex in Belarus
}

\author{
Andrei Tsurykau1 ${ }^{1}$ Q Vladimir Golubkov ${ }^{2}$ \\ ${ }^{1}$ Department of Biology, F. Skorina Gomel State University, Sovetskaja st. 104, 246019 Gomel, Belarus. \\ E-mail: tsurykau@gmail.com \\ ${ }^{2}$ Department of Biology and Ecology, Ya. Kupala Grodno State University, Dovatora st. 3/1, 230015 Grodno, Belarus. \\ E-mail:vgolubkov@tut.by
}

\begin{abstract}
Based on an examination of c. 500 herbarium specimens of the Cladonia pyxidata-chlorophaea complex, this study deals with their morphology, secondary chemistry, habitat requirements and distribution in Belarus. Eleven taxa have been accepted, of which C. conista, C. cryptochlorophaea, C. homosekikaica, C. merochlorophaea, C. monomorpha and C. novochlorophaed are new to the country. Cladonia grayi appears to be the commonest species in the country (c. $40 \%$ of the studied specimens), and C. pyxidata is uncommon in Belarus, known only from 10 localities. The chemotypes of the species and their frequency in Belarus are indicated.
\end{abstract}

Keywords: Cladoniaceae, chemotaxonomy, distribution, ecology

\section{INTRODUCTION}

The currently known lichen biota of Belarus includes c. 550 species of lichenized (Yurchenko, 2011) and 30 species of lichenicolous fungi (Tsurykau et al., 2013; 2014). Initial information about Belarusian lichens relates to the end of the 18th century, when Gilibert (1781) reported 42 lichen species including Cladonia fimbriata (L.) Fr. (as Lichen fimbriatus L.) and C. pyxidata (L.) Hoffm. (as Lichen pyxidatus L.). Since then lichenological studies in Belarus have been sporadic and focused on floristics. The first chemical study was carried out by Tsetterman (1948) when she investigated the genus Cladonia by means of simple spot-test reactions.

The C. chlorophaea complex and its allies are probably the earliest designated group of chemical taxa. The species of this complex are characterized by scyphose podetia covered with farinose to granular soredia, corticated granules and cortical layer, and brown apothecia (Ahti, 1966; Kowalewska et al., 2008). At least 14 major chemotypes, containing some 35 secondary metabolites, have been identified within the complex (Culberson et al., 1985). However, the species status of chemically different entities has been frequently questioned, some authors recognizing chemical variability only at the chemotype, varieties or subspecies level (e.g. Wirth, 1995; Brodo \& Ahti, 1996; James, 2009), while others support chemically defined taxa at the species level (e.g. Holien \& Tønsberg, 1985; Kowalewska et al., 2008; Ahti \& Stenroos, 2013).
In this paper we accept the latter viewpoint although molecular studies do not always provide a clear relationship between morphologically and chemically different individuals (Stenroos et al., 2002; Kotelko \& Piercey-Normore, 2010; Pino-Bodas et al., 2012). Therefore the C. chlorophaea complex requires further molecular investigation with a larger number of samples and more variable gene regions.

In Belarus, the chemical variation of the $C$. pyxidata-chlorophaea group was neglected as thin layer chromatography (TLC) has not been used during species identification. As a result, only six taxa have been recorded from the country to date, namely C. chlorophaea (Flörke ex Sommerf.) Spreng., C. fimbriata (L.) Fr., C. grayi G. Merr. ex Sandst., C. humilis (With.) J. R. Laundon, C. pocillum (Ach.) Grognot and C. pyxidata (L.) Hoffm. However, these species represent a complex of taxa and are in need of revision by means of TLC.

The aim of this study is to present the range of taxa within the Cladonia pyxidata-chlorophaea complex, together with their morphology, chemistry, ecology and distribution in Belarus.

\section{MATERIAL AND METHODS}

Herbarium material loaned from the following Belarusian herbaria, GSU, GRSU, MSK and MSKU (Thiers, [continuously updated]), has been revised. Morphology was checked under a 
stereomicroscope Nikon SMZ-745, and the secondary lichen compounds were studied with TLC in solvent system $\mathrm{C}$ according to the methods of Orange et al. (2001). In all, 507 specimens have been studied; when more than one species was present in a packet, each taxon was counted as a separate specimen.

\section{RESULTS}

Eleven taxa have been found in the material examined, of which six species, C. conista (Ach.) Robbins, C. cryptochlorophaea Asahina, C. homosekikaica Nuno, C. merochlorophaea Asahina, C. monomorpha Aptroot, Sipman \& van Herk and C. novochlorophaea (Sipman) Brodo \& Ahti, are new to Belarus. The occurrence of $C$. chlorophaea s. str. and C. grayi in Belarus was confirmed by thin-layer chromatography. The presence of $C$. humilis has not been confirmed by TLC, and therefore should be excluded from the Belarusian lichen list. Five taxa, C. conista, C. cryptochlorophaea, C. homosekikaica, C. novochlorophaea and C. pocillum, are known only from very few locations and may be endangered in Belarus. C. grayi appears to be the most widely distributed and commonest species in the country.

\section{THE SPECIES}

Cladonia chlorophaea (Flörke ex Sommerf.) Spreng.

Morphology: Podetia mainly small, c. $1 \mathrm{~cm}$ tall, rarely up to c. $2.5 \mathrm{~cm}$ tall, with gradually expanded scyphi up to $0.8 \mathrm{~cm}$ wide, surface of podetia and scyphi covered with granular soredia, sometimes mixed with corticated granules. Apothecia brown and stalked, pycnidia common, on scyphal margins.

Chemistry: Fumarprotocetraric acid complex only.

Ecology: The species is ubiquitous and inhabits a wide range of substrata, namely bark (43 specimens), wood (19), soil (11) and stones (1); corticolous samples were collected from Quercus robur (15), Betula spp. (8), Pinus sylvestris (7), Alnus glutinosa (5), Salix spp. (2), Tilia cordata (2), Acer sp. (1), Larix decidua (1), Populus tremula (1) and Sorbus aucuparia (1). In Belarus, Cladonia chlorophaea is the most indifferent species within the group as far as substrate selectivity is concerned; a similar ecology was also reported for Poland by Kowalewska et al. (2008).

Distribution: The species is widely distributed in Belarus; however, scattered localities in the western and eastern parts of the country have been recorded (Fig. 1A). C. chlorophaea is a cosmopolitan lichen, commonly reported from all continents including the Antarctic region (Archer, 1983; Stenroos, 1993; Kowalewska et al., 2008; Ahti \& Stenroos, 2013).

Notes: Individuals of $C$. chlorophaea are often morphologically similar to $C$. grayi and $C$. merochlorophaea and thus may be mistaken for these species.

Selected specimens examined: Brest region, Malorita district, $10 \mathrm{~km} \mathrm{SE}$ of Malorita town, river Rita valley, $51^{\circ} 52^{\prime} \mathrm{N}, 2^{\circ} 06^{\prime} \mathrm{E}$, pine forest, on soil, 19.09.1984, leg. V. Golubkov (MSK); Vitebsk region, Rossony district, 5 $\mathrm{km}$ NW of Gory village, $55^{\circ} 52^{\prime} \mathrm{N}, 2^{\circ} 03^{\prime} \mathrm{E}$, black alder forest, on Alnus glutinosa, 22.06.1986, leg. V. Golubkov (MSK); Gomel region, Gomel district, Kalinino forest, $2 \mathrm{~km} \mathrm{NE}$ of Tereshkovichi village, $52^{\circ} 15^{\prime} \mathrm{N}$, $30^{\circ} 59^{\prime} \mathrm{E}$, pine forest, on Pinus sylvestris, 02.10.2012, leg. A. Tsurykau (GSU-1946); Grodno region, Svisloch district, Belovezhskaja Puscha National Park, Yazven forest, close to Nemerzha village, $52^{\circ} 50 ' \mathrm{~N}, 2^{\circ} 02^{\prime} \mathrm{E}$, bank of small river, on Salix sp., 21.07.1984, leg. V. Golubkov (MSK); Minsk region, Lahoisk district, Lahoisk town, $54^{\circ} 12^{\prime} \mathrm{N}, 27^{\circ} 50^{\prime} \mathrm{E}$, oak forest, on soil, 16.04.1972, leg. V. Golubkov (MSKU-1433); Mogilev region, Osipovichi region, close to Elizovo village, $53^{\circ} 24^{\prime} \mathrm{N}, 28^{\circ} 59^{\prime} \mathrm{E}$, pine forest, on lignum, 08.06.1960, leg. D.K. Ges' (GSU-1974).

Number of specimens examined: 77.

Relevant literature: For a detailed description and further important notes see Ahti (1966), Ferry \& Pickering (1989), Brodo \& Ahti (1996), Ahti (2000), Ahti \& Hammer (2002), Stenroos et al. (2002), Kowalewska et al. (2008), James (2009), Ahti \& Stenroos (2013) and Osyczka (2013).

\section{Cladonia conista (Nyl.) Robbins}

Morphology: Podetia up to $2 \mathrm{~cm}$ high, greyish, simple, with regular, goblet-shaped scyphi up to $0.7 \mathrm{~cm}$ wide, phyllidia and squamules absent, marginal proliferations not seen. Upper part of the stalk and cups with farinose soredia, nonsorediate part of the stalk smoothly corticate. Apothecia not seen, pycnidia on margins of scyphi. 

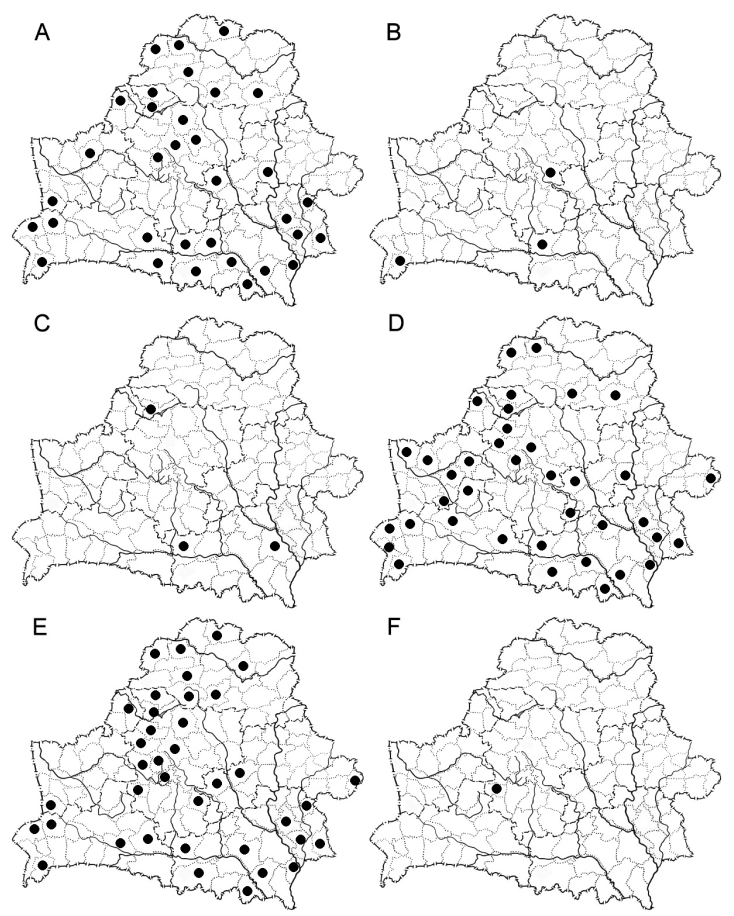

Fig. 1. Distribution of Cladonia chlorophaea (A), C. conista (B), C. cryptochlorophaea (C), C. fimbriata (D), C. grayi (E) and C. homosekikaica $(\mathrm{F})$ in Belarus.

Chemistry: Fumarprotocetraric and bourgeanic acids.

Ecology: According to Holien \& Tønsberg (1985) and Kowalewska et al. (2008), C. conista usually grows on soil in well-lit habitats. In Belarus, it was found in pine and oak woodlands growing on soil and at the basis of aspens.

Distribution: New to Belarus, where it is rare, being known only from three localities in the southern and central parts of the country (Fig. 1B). Cladonia conista is a cosmopolitan lichen commonly reported from all continents except Antarctica (Ahti \& Stenroos, 2013).

Notes: The species is almost indistinguishable from morphologically similar C. humilis (With.) J. R. Laundon despite its phylogenetic distance (Pino-Bodas et al., 2012). Cladonia conista differs by its taller podetia, producing bourgeanic acid and continental distribution, while C. humilis has shorter podetia, produces atranorin and grows along the coastline (Holien \& Tønsberg, 1985; Kowalewska et al., 2008). In Belarus C. humilis was reported by Golubkov \& Yesis (1997) and later by Bely (2011). The cited specimens were re-identified during our revision; according to current knowledge, this oceanic species does not occur in Belarus and should be excluded from the present list of taxa.

Specimens examined: Brest region, Malorita district,

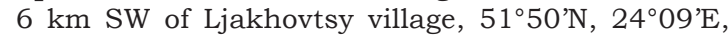
pine forest, on soil, 20.09.1984, leg. V. Golubkov (MSK); Gomel region, Zhitkovichi district, Pripyatsky National Park, Pererovo forest, close to Khlupinskaja Buda village, $52^{\circ} 02^{\prime} \mathrm{N}, 28^{\circ} 09^{\prime} \mathrm{E}$, oak forest, on aspen, 24.08.1982, leg. V. Golubkov (MSK); Minsk region, Pukhovichi district, Mateevichi Reserve, Talk forest, $53^{\circ} 21^{\prime} \mathrm{N}, 28^{\circ} 18^{\prime} \mathrm{E}$, pine forest, on soil, 13.04.2011, leg. A. Yatsyna (MSK-7217).

Number of specimens examined: 3.

Relevant literature: For a detailed description and further important notes see Ahti (1966), Holien \& Tønsberg (1985), Archer (1989), Ahti (2000), Kowalewska et al. (2008), Pino-Bodas et al. (2012), Osyczka (2013), and Ahti \& Stenroos (2013).

\section{Cladonia CRYPTOChlorophaEa Asahina}

Morphology: Podetia up to $1.2 \mathrm{~cm}$ tall, brownish or greenish-grey, with regular scyphi up to 0.5 $\mathrm{cm}$ wide, sometimes with proliferations, surface of podetia is roughly corticate with spherical granules and phyllidia, macrosquamules absent. Apothecia not seen, pycnidia on margins of scyphi.

Chemistry: Cryptochlorophaeic, paludosic and fumarprotocetraric acids, sometimes accompanied by 4-O-methylcryptochlorophaeic acid.

Ecology: The species was found in open and sun-exposed sites, including pine forests and riversides, growing on soil.

Distribution: New to Belarus, being recorded from three localities in Gomel and Minsk regions (Fig. 1C). C. cryptochlorophaea is a cosmopolitan lichen known from all continents, except Antarctica, and mostly confined to boreal zone (Archer, 1983; Ahti \& Stenroos, 2013).

Notes: Morphologically C. cryptochlorophaea is similar to C. grayi, C. merochlorophaea and C. novochlorophaea but differs chemically by producing cryptochlorophaeic and paludosic acids, 
almost always accompanied by the fumarprotocetraric acid complex in Europe (Ahti, 1966; Kowalewska et al., 2008; Ahti \& Stenroos, 2013).

Specimens examined: Gomel region, Zhitkovichi district, Pripyatsky National Park, Ozerany forest, $51^{\circ} 59$ 'N, $27^{\circ} 51^{\prime} \mathrm{E}$, pine forest, on soil, 23.06.1971, leg. O. P. Shakhrai (GSU-91); Rechitsa district, close to Borkhov village, $53^{\circ} 14, \mathrm{~N}, 30^{\circ} 19, \mathrm{E}$, bank of the river Dnieper, on soil, 19.05.1967, leg. N. V. Gorbach (MSK); Minsk region, Vileika district, $1.5 \mathrm{~km}$ SE of Ljudvinovo village, $54^{\circ} 34, \mathrm{~N}, 27^{\circ} 15, \mathrm{E}$, pine forest, on soil, 26.06.1984, leg. V. Golubkov (MSK).

Number of specimens examined: 4.

Relevant literature: For a detailed description and further important notes see Ahti (1966), Holien \& Tønsberg (1985), Ferry \& Pickering (1989), Ahti (2000), Kowalewska et al. (2008), Osyczka (2013), and Ahti \& Stenroos (2013).

Cladonia fimbriata (L.) Fr.

Morphology: Podetia up to c. $3.5 \mathrm{~cm}$ tall, with goblet-shaped and, usually, abruptly expanded scyphi, up to $0.9 \mathrm{~cm}$ wide, sometimes with proliferations, surface of podetia and scyphi covered with farinose soredia, very rarely base of the stalk corticate. Apothecia rare, stalked, simple, brown, pycnidia on podetial margins.

Chemistry: Fumarprotocetraric acid complex only.

Ecology: The species is ubiquitous and inhabits a wide range of substrata. In Belarus it prefers well-lit open pine, oak and birch forests. Some specimens were found in shaded spruce habitats and in urban areas. The species was found on soil (28), Pinus sylvestris (23), wood (22), Quercus robur (8), Betula spp. (7), stones (4), Alnus glutinosa (3), Fraxinus excelsior (1), Populus tremula (1) and Tilia cordata (1).

Distribution: Cladonia fimbriata is a widespread lichen known from all continents except for tropic regions (Osyczka \& Olech, 2005; Ahti \& Stenroos, 2013); it is common in Belarus (Fig. 1D).

Notes: The species is the most easily recognizable in the field by its very characteristic morphology. When typically developed, it has a microsquamulose primary thallus, which sometimes breaks up into granular powdery crust, and tall, regular, goblet-shaped podetia covered with farinose soredia. In most cases we found the inner part of scyphi to be brownish as it was mentioned by Ahti \& Stenroos (2013).

In Belarus C. conista is the most similar species to specimens of $C$. fimbriata with corticate stalk, but it differs chemically. In some cases $C$. chlorophaea forms regular goblet-shaped podetia, but it differs by having granular soredia, and generally smaller stalks (see Osyczka, 2013).

Selected specimens examined: Brest region, Pruzhany district, Belovezhskaja Puscha National Park, Pererovo forest, $4 \mathrm{~km} \mathrm{~W}$ Viskuli steading, $52^{\circ} 37$, N, $24^{\circ} 00$, E, oak forest, on Quercus robur, 20.06.1983, leg. V. Golubkov (MSK); Vitebsk region, Lepel district, Berezinsky biosphere reserve, close to Staisk village, on soil, 17.07.1978, leg. N. N. Kobzar (MSK); Gomel region, Buda-Koshelevo district, Klenovitsa village, on soil, 21.10.2003, leg. A. Tsurykau (GSU-96); Grodno region, Novogrudok district, close to Rutka 1st village, $53^{\circ} 34^{\prime} \mathrm{N}, 2^{\circ} 53$ 'E, spruce forest, on soil, 08.05.2012, leg. S. K. Bakei (MSK-10773); Minsk region, Volozhin district, close to Vishnevo village, $54^{\circ} 08^{\prime} \mathrm{N}, 26^{\circ} 11^{\prime} \mathrm{E}$, on stone, 19.07.2007, leg. V. N. Tikhomirov (MSKU2397); Mogilev region, Bykhov district, 4 km S Bykhov town, floodplain of the river Dnieper, on Quercus robur, 28.06.1959, leg. N. V. Gorbach (MSK).

Number of specimens examined: 114.

Relevant literature: For a detailed description and further important notes see Ahti (1966), Ferry \& Pickering (1989), Brodo \& Ahti (1996), Ahti (2000), Ahti \& Hammer (2002), Kowalewska et al. (2008), James (2009), Osyczka (2013), and Ahti \& Stenroos (2013).

\section{Cladonia grayi G. Merr. ex Sandst.}

Morphology: Podetia up to $4.5 \mathrm{~cm}$ tall, with goblet or trumpet-shaped scyphi up to c. $1 \mathrm{~cm}$ wide, often with proliferations, surface of podetia and scyphi covered with granular soredia, verrucose, phyllidiate, sometimes eroded. Apothecia ochraceous to brown and stalked, pycnidia on scyphal margins.

Chemistry: Two chemotypes are recognized in Belarus: grayanic acid always accompanied by 4-O-demethylgrayanic acid (chemotype I), and additionally substances of the fumarprotocetraric acid complex (chemotype II). Ahti \& Stenroos (2013) reported chemotype I to be somewhat more frequent in Nordic countries, while Kowalewska et al. (2008) noted that $81 \%$ of specimens produced fumarprotocetraric acid in Poland. In Belarus, both chemotype I (114 specimens) and chemotype II (108) are similarly frequent. 
Ecology: The species is mostly found in pine forests (90\% of the studied material) of varying humidity, from wet boggy areas to extremely dry Cladonia-type pine stands. C. grayi inhabits $P i_{-}$ nus sylvestris (93), soil (72), wood (32), Juniperus communis (5), Quercus robur (3), Betula pendula (3), Carpinus betulus (2), Alnus glutinosa (1), and Picea abies (1). We noted that chemotype I is mostly confined to acid bark and inhabits pine trees, while chemotype II prefers soil and wood rather than tree bark in Belarus (Fig. 2).

Distribution: In Belarus Cladonia grayi appears to be the most widely distributed and commonest species within the group (Fig. 1E). This widespread and common species was reported from all continents except Antarctica (Kowalewska et al., 2008; Ahti \& Stenroos, 2013).

Notes: There are no clear morphological characters that allow one to recognize this species in the field and therefore TLC is the only way to determine C. grayi. Thus, only 8 specimens had been previously identified correctly, while 90\% of the currently studied material was found in collections of C. chlorophaea, C. pyxidata and C. fimbriata.

Selected specimens examined: Brest region, Kamenets district, Belovezhskaja Puscha National Park, Dmitrovichi forest, $1 \mathrm{~km}$ SE Kamenjuki village, $52^{\circ} 32^{\prime} \mathrm{N}, 23^{\circ} 48^{\prime} \mathrm{E}$, pine forest, on Juniperus communis, 23.07.1983, leg. V. Golubkov (MSK); Vitebsk region, Shumilino district, $2.5 \mathrm{~km} \mathrm{~W}$ Vishnja village, $55^{\circ} 26^{\prime} \mathrm{N}, 29^{\circ} 16^{\prime} \mathrm{E}$, raised bog, on lignum, 18.07.1985,

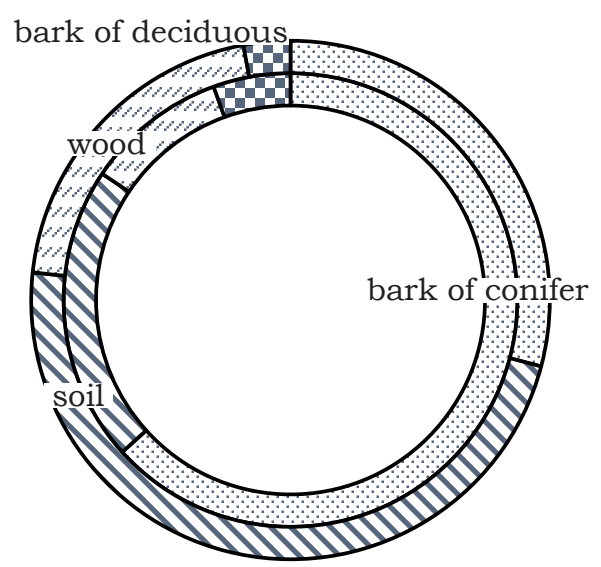

Fig. 2. Substrate selectivity of chemotype I (inner circle) and chemotype II (outer circle) of Cladonia grayi in Belarus. leg. V. Golubkov (MSK); Gomel region, Gomel district, Dolgolesskoje forest, $0.5 \mathrm{~km}$ NE of Dolgolesie village, $52^{\circ} 16^{\prime} \mathrm{N}, 30^{\circ} 44^{\prime} \mathrm{E}$, pine forest, on Pinus sylvestris, 07.08.2013, leg. A. Tsurykau (GSU-1864); Grodno region, Svisloch district, Belovezhskaja Puscha National Park, close to Rudnja (Dobrovolja) village, $52^{\circ} 53^{\prime} \mathrm{N}$, $24^{\circ} 00^{\prime} \mathrm{E}$, on soil in forest, 23.09.1981, leg. V. Golubkov (MSK); Minsk region, Molodechno district, close to Udranka village, $54^{\circ} 11^{\prime} \mathrm{N}, 27^{\circ} 14^{\prime} \mathrm{E}$, pine forest, on soil, 12.08.2004, leg. A. K. Khramtsov (MSKU-2432); Mogilev region, Osipovichi district, $1.5 \mathrm{~km} \mathrm{NW}$ of Elizovo village, on Betula pendula, 03.07.1959, leg. N. V. Gorbach (MSK).

Number of specimens examined: 222.

Relevant literature: For a detailed description and further important notes see Ahti (1966), Holien \& Tønsberg (1985), Brodo \& Ahti (1996), Ahti (2000), Kowalewska et al. (2008), Osyczka (2013), and Ahti \& Stenroos (2013),

\section{Cladonia homosekikaica Nuno}

Morphology: Podetia up to $1.8 \mathrm{~cm}$ high, with regular cups, without proliferations, up to 0.4 $\mathrm{cm}$ wide, surface of podetia continuously corticate on basal parts and finely sorediate on upper parts, podetial squamules. Pycnidia and apothecia not seen.

Chemistry: Two chemotypes are recognized, I with homosekikaic and sekikaic acids, and II additionally contains substances of the fumarprotocetraric acid complex (Ahti \& Stenroos, 2013). In the Belarusian specimen homosekikaic, sekikaic and fumarprotocetraric acids were detected.

Ecology: The only specimen was collected from wood.

Distribution: New to Belarus, where it is known from a single locality (Fig. 1F). World distribution data on C. homosekikaica are scarce; it has rarely been reported from Europe, Asia, North America and Australia (Archer, 1983; Ahti \& Stenroos, 2013).

Notes: Morphologically C. homosekikaica resembles C. fimbriata, but it differs chemically. The species has similar chemistry to C. novochlorophaea, but the latter differs by its verrucose podetial surface, eroded scyphal margins exposing a darkened medulla and lacking soredia.

Specimen examined: Minsk region, Nesvizh district, Nesvizh forest, Alba forest cottage, $53^{\circ} 12, \mathrm{~N}, 26^{\circ} 38 \mathrm{E}$, on wood, 23.06.1960, leg. N. V. Gorbach (MSK). 
Number of specimens examined: 1 .

Relevant literature: For a detailed description and further important notes see Kowalewska et al. (2008), and Ahti \& Stenroos (2013).

\section{Cladonia merochlorophaea Asahina}

Morphology: Podetia up to c. $3 \mathrm{~cm}$ tall, brownishgrey to brownish-green, with gradually flaring, up to $1 \mathrm{~cm}$ wide, simple, rarely proliferating from margins scyphi, surface of podetia and scyphi areolate-corticate, covered by coarse granules and verruculae, phyllidia frequent. Apothecia stalked and brown, pycnidia infrequent, on podetial margins.

Chemistry: Merochlorophaeic and 4-O-methylcryptochlorophaeic acids with related substances (chemotype I), and additionally with fumarprotocetraric acid complex (chemotype II). In Belarus, $67 \%$ specimens contain fumarprotocetraric acid; Holien \& Tønsberg (1985) reported a similar proportion for Norway, while in Poland almost $90 \%$ of specimens produce fumarprotocetraric acid (Kowalewska et al., 2008).

Ecology: C. merochlorophaea is mainly an epigeic lichen confined to open habitats (Holien \& Tønsberg, 1985). In Belarus it is found in welllit pine forests $(71 \%$ of the studied material) inhabiting dry and mesic localities in Cladonia spp., Calluna vulgaris, Pteridium aquilinum, Pleurozium schreberi and Vaccinium myrtillus types of pine stands. The frequency on different substrata is as follows: soil (19), Pinus sylvestris (5), Betula pendula (2), wood (2) and Juniperus communis (1).

Distribution: New to Belarus, where it is mainly known from the southern part of the country (Fig. 3A). Cladonia merochlorophaea is cosmopolitan, being reported from all continents, except Antarctica (Archer, 1983; Kowalewska et al., 2008).

Notes: Morphologically C. merochlorophaea resembles C. cryptochlorophaea, but the latter differs chemically by producing cryptochlorophaeic acid.

Selected specimens examined: Brest region, Kamenets district, Belovezhskaja Puscha National Park, Pererovo forest, close to Kamenjuki village, $52^{\circ} 40^{\prime} \mathrm{N}, 23^{\circ} 55^{\prime} \mathrm{E}$, spruce forest, on Pinus sylvestris, 23.07.1983, leg. V. Golubkov (MSK); Gomel region, Buda-Koshelevo district, Chebotovichi forest, $1.5 \mathrm{~km}$ SW of Elenets village, $52^{\circ} 37^{\prime} \mathrm{N}, 30^{\circ} 18^{\prime} \mathrm{E}$, pine forest, on
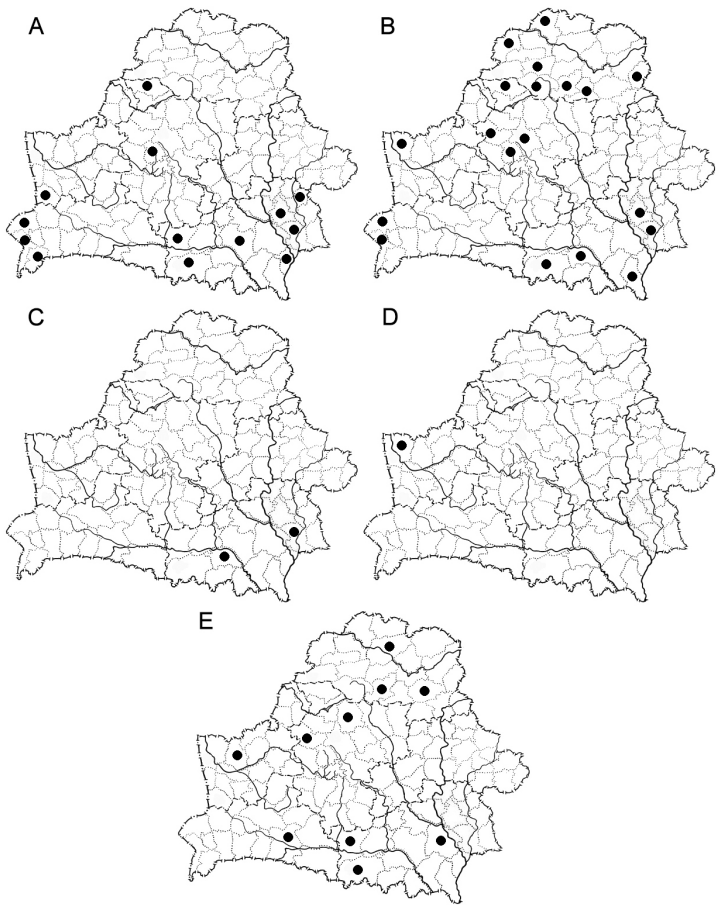

Fig. 1. Distribution of Cladonia merochlorophaea (A), C. monomorpha (B), C. novochlorophaea (C), C. pocillum (D) and C. pyxidata (E) in Belarus.

Pinus sylvestris, 13.07.2013, leg. A. Tsurykau (GSU1918); Grodno region, Svisloch district, Belovezhskaja Puscha National Park, close to Rudnja (Dobrovolja) village, $52^{\circ} 53^{\prime} \mathrm{N}, 2^{\circ} 00^{\prime} \mathrm{E}$, on soil in forest, 23.09.1981, leg. V. Golubkov (MSK); Minsk region, Dzerzhynsk district, Negoreloje forest, close to Garbuzy village, $53^{\circ} 34^{\prime} \mathrm{N}, 27^{\circ} 03^{\prime} \mathrm{E}$, birch forest, on soil, 15.07.1968, leg. N. V. Gorbach (MSK).

Number of specimens examined: 39.

Relevant literature: For a detailed description and further important notes see Ahti (1966), Holien \& Tønsberg (1985), Ferry \& Pickering (1989), Ahti (2000), Kowalewska et al. (2008), Osyczka (2013), and Ahti \& Stenroos (2013).

Cladonia monomorpha Aptroot, Sipman \& van Herk

Morphology: Podetia up to c. $2 \mathrm{~cm}$ tall, with trumpet-shaped and gradually expanded, simple, rarely with proliferations scyphi, up to 0.9 $\mathrm{cm}$ wide, surface of podetia and scyphi covered with bullate corticate plates, often with whitish 
margins. Apothecia in glomerulose accumulations, always on marginal proliferations, pycnidia infrequent, on podetial margins.

Chemistry: Fumarprotocetraric acid complex.

Ecology: In Belarus C. monomorpha is mostly confined to well-lit open habitats growing on soil (22) and stones (5) which agrees with other investigations (Aptroot et al., 2001; Kowalewska et al., 2008).

Distribution: New to Belarus, where it is the commonest species within the C. pyxidata complex. Most of the records come from the northern part of the country (Fig. 3B). C. monomorpha was previously reported from Europe, Asia and North America (Kowalewska et al., 2008).

Notes: The species was recently described from Europe (Aptroot et al., 2001) on the basis of its morphology. The presence of bullate plates (commonly with whitish margins) and glomerulose apothecia clearly separates C. monomorpha from the related $C$. pyxidata and $C$. pocillum. The most morphologically similar C. magyarica Vain. differs chemically as it contains atranorin.

Selected specimens examined: Brest region, Kamenets district, Belovezhskaja Puscha National Park, Korolevo-Mostovskoe forest, $52^{\circ} 35^{\prime} \mathrm{N}, 23^{\circ} 52^{\prime} \mathrm{E}$, pine forest, on soil, 14.07.1983, leg. V. Golubkov (MSK); Vitebsk region, Verkhnedvinsk district, $2 \mathrm{~km} \mathrm{~S}$ of Sukali village, island of Asveja lake, $56^{\circ} 02^{\prime} \mathrm{N}, 28^{\circ} 07^{\prime} \mathrm{E}$, on soil, 18.06.1986, leg. V. Golubkov (MSK); Gomel region, Buda-Koshelevo district, close to RudnjaOlkhovka village, $52^{\circ} 32^{\prime} \mathrm{N}, 30^{\circ} 22^{\prime} \mathrm{E}$, pine forest, on soil, 21.10.2003, leg. A. Tsurykau (GSU-32); Grodno region, Grodno district, $2 \mathrm{~km} \mathrm{~N}$ of Grodno city, 13th fort Grodno fortress, $53^{\circ} 44^{\prime} \mathrm{N}, 23^{\circ} 48^{\prime} \mathrm{E}$, on soil, 25.06.2013, leg. S. K. Bakei (GRSU); Minsk region, Dzerzhinsk district, $2 \mathrm{~km} \mathrm{~S}$ of Rubezhevichi village, $53^{\circ} 40^{\prime} \mathrm{N}, 26^{\circ} 51^{\prime} \mathrm{E}$, on siliceous stone, 05.05.1989, leg. V. Golubkov (MSK).

Number of specimens examined: 32 .

Relevant literature: For a detailed description and further important notes see Aptroot et al. (2001), Kowalewska \& Kukwa (2004), and Kowalewska et al. (2008).

Cladonia novochlorophaea (Sipman) Brodo \& Ahti

Morphology: Podetia up to $1.5 \mathrm{~cm}$ tall, brownish or blackish, with scyphi up to $0.9 \mathrm{~cm}$ wide, simple to proliferating from margins, surface of podetia and outer part of the scyphi roughly corticate, verruculose, squamulose, inner part of the scyphi eroded, covered with cortical plates. Apothecia stalked, brown, pycnidia develop on scyphal margins.

Chemistry: Homosekikaic, sekikaic and fumarprotocetraric acids.

Ecology: C. novochlorophaea was grows on soil (1) and Pinus sylvestris (1) in open habitats dominated by pines and birches.

Distribution: New to Belarus, being known only from two localities in the Gomel region, in the south-eastern part of the country (Fig. 3C). C. novochlorophaea has been reported from Europe, North and South America, New Zealand, and the Antarctic region (Øvstedal \& Lewis Smith, 2001; Ahti \& Stenroos, 2013).

Notes: C. novochlorophaea is similar to C. merochlorophaea, but, when typically developed, has very characteristic eroded scyphal margins, revealing darkened medulla, and is never clearly sorediate. The species has a similar chemistry to $C$. homosekikaica, but the latter differs by its continuously corticated basal parts and finely sorediate upper parts of podetia.

Specimens examined: Gomel region, Gomel district, Staro-Djatlovichskoje forest, $2.5 \mathrm{~km} \mathrm{SW}$ of Staryje Djatlovichi village, $52^{\circ} 13^{\prime} \mathrm{N}, 30^{\circ} 49^{\prime} \mathrm{E}$, pine forest, on pine, 01.08.2013, leg. A. Tsurykau (GSU-1921); Mazyr district, close to Provtjuki village, $51^{\circ} 54^{\prime} \mathrm{N}, 29^{\circ} 22^{\prime} \mathrm{E}$, birch forest, on soil, 26.08.1977, leg. V. Golubkov (MSKU-2310).

Number of specimens examined: 2 .

Relevant literature: For a detailed description and further important notes see Brodo \& Ahti (1996), Ferry \& Pickering (1989), Ahti (2000), Kowalewska et al. (2008), Osyczka (2013), and Ahti \& Stenroos (2013)

\section{Cladonia Pocillum (Ach.) Grognot}

Morphology: Primary thallus well-developed, rosette-like. Podetia up to c. $1 \mathrm{~cm}$ tall, with gradually expanded simple scyphi up to $0.5 \mathrm{~cm}$ wide, surface of podetia and scyphi irregularly corticate, areolate, verrucose, squamulose, phyllidiate. Apothecia simple and brown, pycnidia pyriform, on scyphal margins.

Chemistry: Fumarprotocetraric acid complex.

Ecology: The specimen was found on mosscovered concrete of World War I fortifications. 
Distribution: The present study confirmed only one specimen to be C. pocillum (Fig. 3D). It was previously reported from different sites in Belarus (e.g. Golubkov, 1993; 2013), but these samples appeared to be mainly C. monomorpha, or had been lost in MSK, so there was no possibility of checking their identity. The species is widespread on all continents, including Antarctica (Stenroos, 1993; Kowalewska et al., 2008).

Notes: C. pocillum is very similar to C. pyxidata, but it has a conspicuous rosette-like primary thallus and prefers calcareous substrata. Substrate selectivity of C. pocillum plays a significant role in its taxonomical concept.

Specimen examined: Grodno region, Grodno district, $1.5 \mathrm{~km} \mathrm{~W}$ of Kamenka village, Grodno fortress (6th fort), $53^{\circ} 35^{\prime} \mathrm{N}, 23^{\circ} 46^{\prime} \mathrm{E}$, on moss-covered concrete, 21.04.2011, leg. V. Golubkov (GSU-1568).

Number of specimens examined: 1 .

Relevant literature: For a detailed description and further important notes see Ahti (1966), Ahti (2000), Ahti \& Hammer (2002), Kowalewska et al. (2008), Kotelko \& Piercey-Normore (2010), and Ahti \& Stenroos (2013).

Cladonia pyxidata (L.) Hoffm.

Morphology: Podetia up to c. 2.5 tall, trumpetshaped and, usually, gradually flaring from the base scyphi, up to $0.6 \mathrm{~cm}$ wide, surface of podetia and scyphi covered with an irregular areolate cortex. Apothecia simple or ring-like, pycnidia on podetial margins.

Chemistry: Fumarprotocetraric acid complex.

Ecology: In Belarus the species is mainly found in well-lit Scots pine forests growing on soil. One specimen was collected from stones.

Distribution: Although C. pyxidata was previously frequently reported from Belarus, it is currently known from only 10 localities (Fig. $3 \mathrm{E})$. Most of the 64 samples housed in herbaria as C. "pyxidata" appeared to be other species, mainly C. grayi, C. chlorophaea and C. monomorpha; only one specimen was re-identified as $C$. pyxidata s.str. The species is known worldwide (Osyczka \& Olech, 2005; Ahti \& Stenroos, 2013).

Notes: In the present concept, the species is distinguishable from similar taxa by its irregular areolate cortex on podetial surface, and simple, globose or ring-like apothecia (Aptroot et al., 2001). C. pyxidata is very similar to $C$. pocillum, which differs by forming rosette-like basal squamules. According to Ahti \& Hammer (2002) and Kowalewska et al. (2008), the latter is an ecomorph of C. pyxidata growing on basic substrata. We also support this idea since only a few samples with a rosette-like primary thallus growing on acidic substrata were found, but molecular studies should be performed to evaluate the true status of these species.

Selected specimens examined: Brest region, Pinsk district, Logishin forest, $7 \mathrm{~km}$ SW Logishin town, $52^{\circ} 17^{\prime} \mathrm{N}, 25^{\circ} 55^{\prime} \mathrm{E}$, pine forest, on soil, 23.04.1989, leg. V. Golubkov (MSK); Vitebsk region, Senno district, $1 \mathrm{~km} \mathrm{~N}$ of Buda village, $54^{\circ} 48^{\prime} \mathrm{N}, 30^{\circ} 06^{\prime} \mathrm{E}$, on soil, 21.04.1990, leg. V. Golubkov (MSK); Gomel region, Lelchitsy district, Pripyatsky National Park, Mlynok forest, $51^{\circ} 55^{\prime} \mathrm{N}, 27^{\circ} 58^{\prime} \mathrm{E}$, pine forest, on soil, 05.07.1972, leg. A. Klakotskaja (MSK); Grodno region, Shuchin district, close to Yakubovichi village, $53^{\circ} 51^{\prime} \mathrm{N}$, $24^{\circ} 28^{\prime} \mathrm{E}$, on stone, 15.08.1999, leg. V. Golubkov (MSK); Minsk region, Logoisk district, $1 \mathrm{~km}$ E of Svaby village, $54^{\circ} 17^{\prime} \mathrm{N}, 28^{\circ} 10^{\prime} \mathrm{E}$, on soil, 01.07.1987, leg. V. Golubkov (MSK).

Number of specimens examined: 13.

Relevant literature: For a detailed description of the C. pyxidata, separating it from the $C$. monomorpha and further important notes see Aptroot et al. (2001), Kowalewska et al. (2008), and Kotelko \& Piercey-Normore (2010).

\section{ACKNOWLEDGEMENTS}

We are most grateful to Dr Dmitrii Tretyakov, Dr Valentina Polyksenova, Aleksandr Yatsyna and Svetlana Drobyshevskaja (Minsk) for providing access to the specimens housed in the MSK and MSKU herbaria, to Dr Tiina Randlane (Tartu) and an anonymous reviewer for the constructive comments and suggestions on the manuscript, and to Prof Mark R. D. Seaward (Bradford) for the linguistic corrections and other valuable improvements.

\section{REFERENCES}

Ahti, T. 1966. Correlation of the chemical and morphological characters in Cladonia chlorophaea and allied lichens. Annales Botanici Fennici 3: 380-389.

Ahti, T. 2000. Cladoniaceae. Flora Neotropica Monograph 78: 1-362.

Ahti, T. \& Hammer, S. 2002. Cladonia. In: Nash III, T. H., Ryan, B. D., Gries, C. \& Bungartz, F. (eds). Lichen Flora of the Greater Sonoran Desert Region 1. Arizona State University, Tempe, pp. 131-158. 
Ahti, T. \& Stenroos, S. 2013. Cladonia P. Browne. In: Ahti, T., Stenroos, S. \& Moberg, R. (eds). Nordic Lichen Flora vol. 5. Cladoniaceae. Nordic Lichen Society, Uppsala, pp. 8-87.

Aptroot, A., Sipman, H. J. M. \& van Herk, C. M. 2001. Cladonia monomorpha, a neglected cup lichen from Europe. Lichenologist 33: 271-283. http:/ / dx.doi.org/10.1006/lich.2001.0332

Archer, A. W. 1983. Cladonia chlorophaea sens. lat. in southeastern Australia. Bryologist 86: 251-253. http: / /dx.doi.org/10.2307/3242713

Archer, A. W. 1989. Two new lichens: Cladonia paeminosa and C. humilis var. bourgeanica. Muelleria 7: 1-5.

Bely, P. N. 2011. An annotated list of lichens and lichenicolous fungi in spruce ecosystems in Belarus. Specially protected natural areas of Belarus. Research 6: 146-178. (In Russian).

Brodo, I. M. \& Ahti, T. 1996. Lichens and lichenicolous fungi of the Queen Charlotte Islands, British Columbia, Canada. Canadian Journal of Botany 74: 1147-1180. http:/ /dx.doi.org/10.1139/b96-139

Culberson, C. F., Culberson, W. L. \& Johnson, A. 1985. Orcinol-type depsides and depsidones in the lichens of the Cladonia chlorophaea group (Ascomycotina, Cladoniaceae). Bryologist 88: 380-387. http://dx.doi.org/ 10.2307/3242681

Ferry, B. W. \& Pickering, M. 1989. Studies on the Cladonia chlorophaea complex at Dungeness, England. Lichenologist 21: 67-77. http:/ / dx.doi. org/ 10.1017/S0024282989000083

Gilibert, J. E. 1781. Flora lithuanica inchoata, seu Enumeratio plantarum Quas Circa Grodnam coll'egit et determinavit Joannes Emmanuel Gilibert. Typis S.R.M., Grodnae, pp. 118-119.

Golubkov, V. V. 1993. About some new and rare lichen species for the territory of Belarus. Fungi and lichens in the Baltic region. Abstracts of the 12th International Conference on Mycology and Lichenology. Vilnius, pp 137-138.

Golubkov, V. V. 2013. New and rare lichen species from Belarus (short communication). Actual problems of ecology. Proceedings of IX International Conference. Part 1. Grodno, pp. 22-24. (In Russian).

Golubkov, V. V. \& Yesis, S. M. 1997. Preliminary data on lichens from Minsk Upland. In: Aleksandrovich, A. R. (ed). Actual problems of Environmental studies. Minsk, pp. 66-73. (In Russian).

James, P. W. 2009. Cladonia P. Browne. In: Smith, C. W., Aptroot, A., Coppins, B. J., Fletcher, A., Gilbert, O. L., James, P. W. \& Wolseley, P. A. (eds). The lichens of Great Britain and Ireland. London, pp. 309-338.

Kotelko, R. \& Piercey-Normore, M. D. 2010. Cladonia pyxidata and C. pocillum; genetic evidence to regard them as conspecific. Mycologia 102: 534-545. http://dx.doi.org/10.3852/09-030

Kowalewska, A. \& Kukwa, M. 2004. New records of Cladonia monomorpha (Cladoniaceae, lichenised Ascomycota) from Europe. Herzogia 17: 103-105.
Kowalewska, A., Kukwa, M., Ostrowska, I., Jabłońska, A., Oset, M. \& Szok, J. 2008. The lichens of the Cladonia pyxidata-chlorophaea group and allied species in Poland. Herzogia 21: 61-78.

Motiejunaite, J 2002. Additions to the Lithuanian flora of foliose and fruticose lichens. Botanica Lithuanica 8(1): 69-76.

Orange, A., James, P. W. \& White, F. J. 2001. Microchemical methods for the identification of lichens. British Lichen Society, London. 101 pp.

Osyczka, P. 2013. A morphometric evaluation of the Cladonia chlorophaea group and allied taxa (Cladoniaceae, Ascomycota). Herzogia 26: 49-64. http: / /dx.doi.org/ 10.13158/heia.26.1.2013.49

Osyczka, P. \& Olech, M. 2005. The lichen genus Cladonia of King George Island, South Shetland Islands, Antarctica. Polish Polar Research 26: 107-123.

Øvstedal, D. O. \& Lewis Smith, R. I. 2001. Lichens of Antarctica and South Georgia. A guide to their identification and ecology. Cambridge University Press, Cambridge. $411 \mathrm{pp}$.

Pino-Bodas, R., Ahti, T., Stenroos, S., Martín M. P., \& Burgaz. A. R. 2012. Cladonia conista and C. humilis (Cladoniaceae) are different species. Bibliotheca Lichenologica 108: 161-176.

Stenroos, S. 1993. Taxonomy and distribution of the lichen family Cladoniaceae in the Antarctic and peri-Antarctic regions. Cryptogamic Botany 3: 310-344.

Stenroos, S., Hyvönen, J., Myllys, L., Thell, A. \& Ahti, T. 2002. Phylogeny of the genus Cladonia s. lat. (Cladoniaceae, Ascomycetes) inferred from molecular, morphological, and chemical data. Cladistics 18: 237-278. http://dx.doi. org/10.1111/j.1096-0031.2002.tb00151.x

Thiers, B. [continuously updated]. Index Herbariorum: A global directory of public herbaria and associated staff. New York Botanical Garden's Virtual Herbarium. http://sweetgum.nybg.org/ih/

Tsetterman, N. O. 1948. Cladonia of the BSSR. Uchenye zapiski BSU. Biological Series 7: 110-113. (In Russian).

Tsurykau, A., Suija, A. \& Khramchankova, V. 2013. New records of lichenicolous fungi from the Gomel Region of Belarus. Folia Cryptogamica Estonica 50: 67-71. http:/ /dx.doi.org/10.12697/ fce. 2013.50 .09

Tsurykau, A., Golubkov, V. \& Kukwa, M. 2014. New or otherwise interesting records of lichens and lichenicolous fungi from Belarus. Herzogia 27: 111-120. http://dx.doi.org/10.13158/ heia.27.1.2014.111

Wirth, V. 1995. Die Flechten Baden-Württembergs, Teil 1 \& 2. Ulmer, Stuttgart. 1006 pp.

Yurchenko, E. O. 2011. Lichens of Belarus: an illustrated electronic handbook. K. E. Dovgailo, Minsk. CD-ROM. 
72 Folia Cryptog. Estonica 